\title{
Prioritization of Promising Wadi Wala Watershed (Southern Jordan) Using GIS-Based Morphometric Analysis and Multivariate Statistics
}

\author{
Yahya Farhan $^{1 *}$, Ali Anbar², Dalal Zreqat², Haifa Almohammad³, Sireen Alshawamreh² \\ ${ }^{1}$ Amman, Jordan \\ ${ }^{2}$ Department of Geography, University of Jordan, Amman, Jordan \\ ${ }^{3}$ FAO, Sustainability Land Management Member, Amman, Jordan \\ Email: *wjetfan47962@gmail.com
}

How to cite this paper: Farhan, Y., Anbar, A., Zreqat, D., Almohammad, H. and Alshawamreh, S. (2018) Prioritization of Promising Wadi Wala Watershed (Southern Jordan) Using GIS-Based Morphometric Analysis and Multivariate Statistics. Open Journal of Geology, 8, 135-160.

https://doi.org/10.4236/ojg.2018.82009

Received: December 23, 2017

Accepted: February 9, 2018

Published: February 12, 2018

Copyright (c) 2018 by authors and Scientific Research Publishing Inc. This work is licensed under the Creative Commons Attribution International License (CC BY 4.0).

http://creativecommons.org/licenses/by/4.0/

c)

\begin{abstract}
GIS-based morphometric analysis was employed for prioritization of the Wadi Wala catchment, southern Jordan. Twenty three fourth-order sub-basins were prioritized based on morphometric analysis, then appropriate soil and water conservation measures were proposed. Digital Elevation Model (DEM) and Arc GIS were used to delineate watersheds and to extract the drainage networks, and other required thematic maps (elevation and slope). LANDSAT data was used to prepare land use/land cover map, and a soil map was digitized using Arc GIS software. Linear and shape parameters were computed to prioritize 23 sub-watersheds, and ranks were designated based on the calculated compound parameter (Cp). Sub-basins grouped under a high priority class are exposed to high erosion risk; thus, they are of high potential for applying soil and water conservation measures. The current study substantiates the capability of morphometric analysis method, and geospatial technology in watershed prioritization. The Discriminant Analysis (DA) employed validates the priority classes (high, moderate, and low priority) achieved based on morphometric analysis, where they found statistically distinct from each other. Thus, it can be concluded that prioritization based only on morphometric analysis method is consistent, reliable, and of high capacity using GIS platform. Priority map along with soil, land user/cover, and slope information will help decision makers to execute proper soil and water conservation programs in the rainfed highlands of Jordan.
\end{abstract}

\section{Keywords}

Morphometric Analysis, Prioritization, Soil Erosion Loss, Discriminant 
Analysis, GIS, Jordan

\section{Introduction}

Land degradation in Jordan is induced mainly by runoff soil erosion which was active prehistorically and historically in the rainfed highlands region. Geoarchaeological studies conducted on Paleo-soil erosion in the alluvial deposits of W.Wala in historic time, suggest that historical soil erosion, agricultural intensification, and agricultural terraces, were prevalent over the Levantine highland since the Iron Age [1]. Further, destruction of vegetation cover, intensive exploitation of land resources, and land use abuse entailed high soil erosion rates since the Neolithic and Chalcolithic periods. The presence of field soil erosion features and old agricultural terraces, indicate that the highlands of Jordan have experienced severe soil erosion at least since the Nabatean period, 3000 years ago [2]. Since the 1960s, quantitative and qualitative studies have been performed on soil erosion and conservation in Jordan [3]-[9]. Several studies also reported the occurrence of repetitive heavy rainstorms which induced excessive soil erosion, landslide activity and flooding [10] [11] [12]. The recoded maximum rainfall intensity in $24 \mathrm{hrs}$ ranges between $100 \mathrm{~mm}$ and $150 \mathrm{~mm}$ [13] [14] [15], and the maximum daily intensity $\left(\mathrm{mm} / \mathrm{hr}^{-1}\right)$ varies from 2 and $6.6 \mathrm{~mm} / \mathrm{hr}^{-1}$ [15]. Exceptional daily rainfall intensity recorded was $15 \mathrm{~mm} / \mathrm{hr}^{-1}$ during the $1960 \mathrm{~s}$. Several surveys were performed on soil erosion and conservation for Wadi Ziqlab (Northern Jordan) [9], Wadi Shueib and Wadi Kufrein (Central Jordan) [8], and Wadi Hasa (Southern Jordan) [7]. In situ field measurements on soil erosion were carried out across different bioclimatic regions of Jordan, i.e., sub-humid Mediterranean (Salt, Kufranja, and Jerash areas), semi-arid (Muwaqar and Shuwbak-W. Musa-Petra area), and arid (Azraq area) using different methods/techniques, i.e., splash, sheet, and runoff erosion [16]-[21]. The high estimated soil erosion loss for Wadi Kufranja [22], and Wadi Kerak [23] watersheds using the RUSLE model, reveals that continuous deterioration of top productive soil. Thus, high soil erosion rates seriously endanger the rainfed agricultural sustainability, and the present and future proposed dams in the highlands of Jordan. The predicted average annual sediment yield for Wadi Wala and Wadi Mujib using SWAT model, and the Zarqa River using AGNPS erosion model is also considered a critical threat to W.Wala and W.Mujib reservoirs, and the KTD of the Zarqa River [24]-[28]. Annual and seasonal rainfall erosivity for Jordan have been estimated based on three regression models, and using annual and seasonal precipitation data over a long record ( 40 - 53 years) pertaining to 40 weather stations [29]. Spatial distribution of rainfall erosivity in Jordan is controlled largely by morphological (relief and slope) and climatic factors. Lowest R-Values are found in arid areas (annual rainfall is below $100 \mathrm{~mm}$ ), whereas the highest $\mathrm{R}$-values are found in the northern highlands (annual rainfall approaches $650 \mathrm{~mm}$ ). The correlation 
between annual erosivity and the annual and seasonal precipitation $(\mathrm{mm})$ exhibits a very strong relationship ( $\mathrm{R}$ range from 0.964 to 1.0, and all correlations are significant at 0.01 level, 2 tailed test). Prioritization of sub-watersheds based on morphometric analysis method using GIS and RS techniques, are found to be efficient for large areas (watershed, or sub-watershed scale), and it is fundamental to provide proper soil conservation plan. Adaptation of conservation measures with respect to a priority approach will minimize soil erosion loss, thus increasing moisture in soil profile, and in turn reducing the impact of drought and the possibility of flooding. Finally, prioritization is important for positioning suitable sites for water harvesting, and designing efficient water harvesting structures [30]-[39].

In the light of striking high soil erosion rates and sediment yield loads, distinct sub-basins exhibit potential areas to promote conservation activity, and must be prioritized immediately for soil and water conservation practices to maintain future agricultural sustainability. Quantitative morphometric analysis for watersheds was utilized recently as a successful approach to prioritize sub-basins for soil and water conservation measures [31] [34] [35] [36] [37] [38] [40]-[48]. Morphometric erosion risk parameters represented by linear and shape variables must be computed to prioritize sub-basins for soil conservation. In the recent past, it has been argued that linear parameters maintain a direct relationship with erodibility. Therefore, the highest value ranked as 2 and so on. Alternatively, the shape parameters have an inverse relation with erodibility, thus, the lower their values, the greater the erodibility [31] [36] [41] [42]. Consequently, the lowest value of shape parameter was rated as rank 1 and the second lowest as rank 2 and so on. Compound parameter $(\mathrm{Cp})$ was computed by adding up all the ranks of linear variables, as well as shape variables, and then, dividing by the number of all parameters.

Following the rating of every single morphometric variable, the ranking values for all linear and shape variables referring to each sub-basin are added up for each of the sub-basins to achieve a compound parameter ( $\mathrm{Cp}$ ) score based on the average value of these variables. Furthermore, the sub-basins having the lowest compound parameter score were designated the highest priority, the next higher value was assigned as second priority and so on [38]. Highest priority indicates the greater degree of soil erosion in that particular sub-basin; thus, it is considered a potential area for applying soil conservation measures [45]. Several methods of analysis were employed to perform watershed prioritization. Among these methods is: morphometric analysis based on linear and shape parameters [36] [38] [44]. Moreover, morphometric analysis combined with sediment yield index (SYI) model, and sediment product rate (SPR) was also utilized [40]. Other studies employed morphometric analysis, land use/land cover variables, and sediment yield index [37]. Snyder's synthetic unit hydrograph method has incorporated in the analysis by Singh and Singh [40]. Several prioritization studies combined morphometric analysis with the USLE and RUSLE models for soil loss es- 
timation, or soil erosion susceptibility assessment [49] [50] [51]. Others adopted morphometric indices and Fuzzy Analytical Hierarchy, including the Saaty Analytical Hierarchy Process [52] [53]. Morphometric analysis of linear parameters (bifurcation ratio, drainage density $\left(\mathrm{km} / \mathrm{km}^{2}\right)$, texture ratio, stream frequency, and overland flow $(\mathrm{Km})$ ); and shape parameters (elongation ratio, circularity ratio, shape factor, form factor, and compactness coefficient) are the common parameters employed to calculate the compound parameter $(\mathrm{Cp})$ on which prioritization of sub-watersheds is perceived. It has been reported [30] that the proposed linear and shape morphometric parameters for prioritization are consistent in relation to erodibility. However, the limitations argued regarding morphometric analysis method in prioritization were examined in the present study, and the validity of the priority classes was tested statistically using Discriminant Analysis. It is intended in this study to:

1) prioritize the 23 sub-watersheds of W.Wala using GIS-based morphometric analysis to identify sub-basins of high potential for applying soil and water conservation measures,

2) generate spatial maps displaying the final priority classes by means of GIS tools,

3) propose appropriate soil and water conservation measures for W.Wala in order to minimize soil erosion rates and sediment yield production,

4) test the validity of achieved priority classes (sub-watershed groups) through morphometric analysis by means of Discriminant Analysis (DA).

W.Wala is considered as a promising agricultural watershed, and water resources development, morphometric analysis and the retained information are significant for future soil water conservation planning and water resources management.

\section{Study Area}

The W.Wala catchment comprises the upper part of W. Mujib-Wala watershed. The catchment has a triangular shape with an area of $2063.6 \mathrm{~km}^{2}$. It is located at $35^{\circ} 65^{\prime}$ to $36^{\circ} 30^{\prime} \mathrm{E}$ longitude, and $31^{\circ} 55^{\prime}$ to $31^{\circ} 90^{\prime} \mathrm{N}$ latitude (Figure 1). Elevation varies from $-327 \mathrm{~m}$ (b.s.l) at the confluent point where $\mathrm{W}$. Wala merges with $\mathrm{W}$. Mujib (3 km before the wadi system discharge into the Dead Sea) to $1007 \mathrm{~m}$ (a.s.l) northwest of the watershed (Figure 2). Successive lowering of the Dead Sea base level as a result of uplifting of the eastern shoulder of the Dead Sea Rift, and renewed downward movement of the Rift (during late Tertiary and Quaternary tectonics) [54] caused progressive rejuvenation, river incision and down cutting of W.Wala. Consequently, undulation to moderate slopes $\left(0^{\circ}-5^{\circ}\right),\left(5^{\circ}-10^{\circ}\right)$, and $\left(10^{\circ}-15^{\circ}\right)$ dominate the eastern part of the catchment, whereas, steep slopes (>35) and highly dissected topography characterize the western part (Figure 3). High HI values $(70.0 \%-89.0 \%)$ predominate in the catchment, indicating that W.Wala watershed and the 23 sub-basins are at the youth-age stage of geomorphic evolution. Accordingly, the sub-watersheds have a high possibility for 


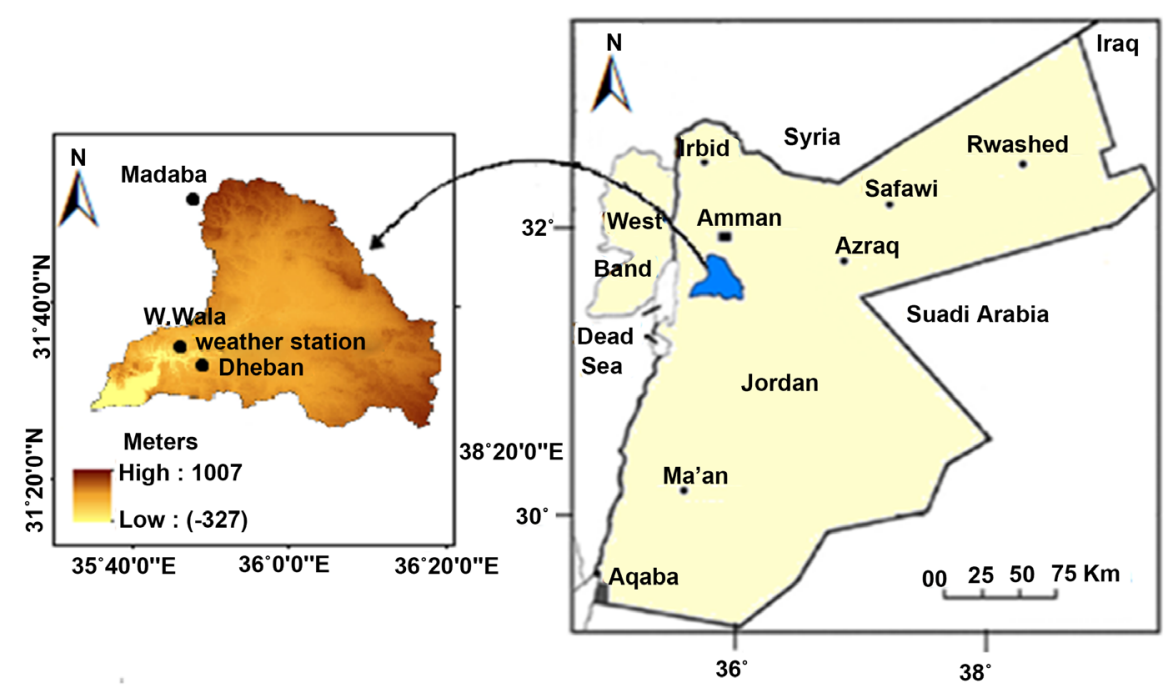

Figure 1. Location of the study area.

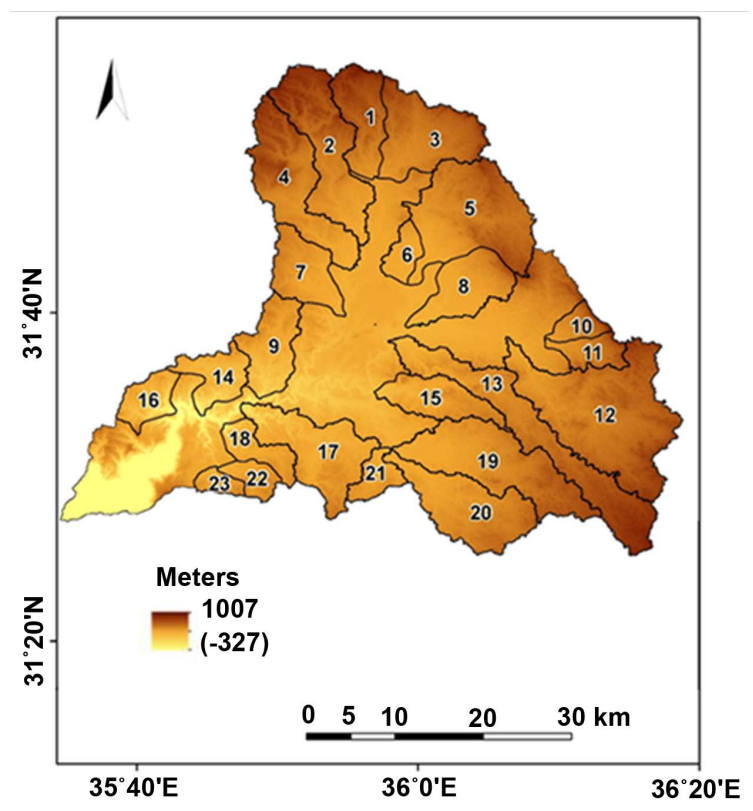

Figure 2. DEM of W.Wala.

flooding, high soil erosion rates, high sediment load, and landsliding activity. Cretaceous carbonate rocks outcrop in most of the W.Wala watershed. The massive limestone unit of the Turonian age is the oldest rock exposed. The average thickness of this unit is $67 \mathrm{~m}$.

The massive chalk limestone unit is the youngest, and ranges in age from early Paleocene the Middle Eocene [55]. Basalt flows of the Pleistocene age are exposed in the upper W.Wala. Quaternary deposits of fluviatile and lacustrine gravels cover part of the deep tributaries of the catchment. The most productive aquifers in the watershed are those restricted to the Amman-Wadi As Sir Limestone formation (Upper Cretaceous) termed A7-B1 [4]. In 2003, a reservoir was constructed on W.Wala with a capacity of $10 \mathrm{MCM}$, and the future plan is to 


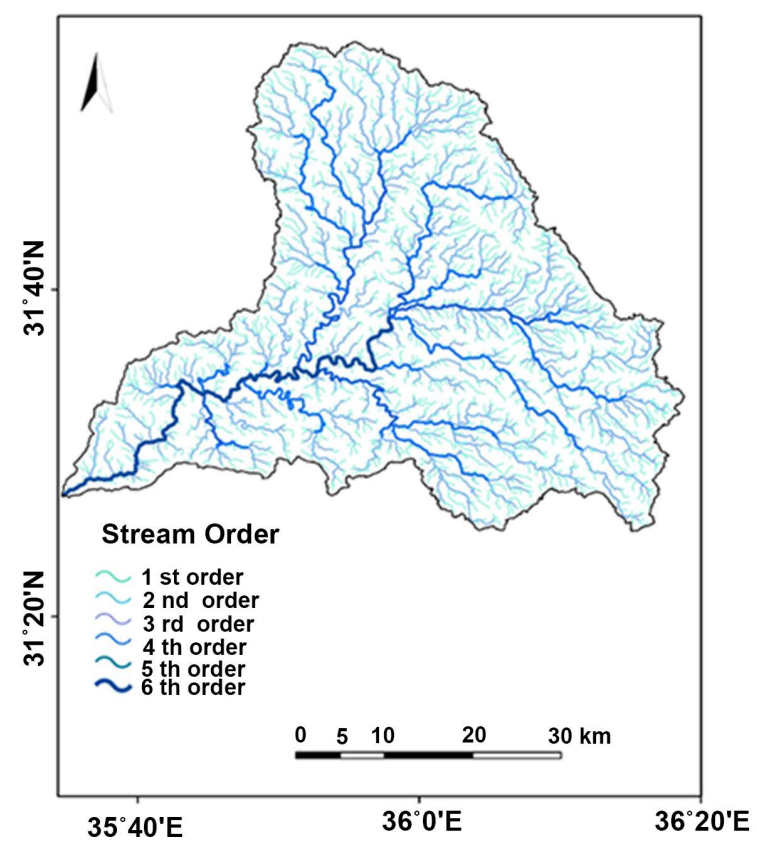

Figure 3. Stream order.

raise the height of the reservoir to store $26 \mathrm{MCM}$. The purpose of the reservoir is to recharge the groundwater, to provide water for springs and pumping wells, and to practice irrigated agriculture on a larger scale.

Hydrological prospecting and assessment of water resources is in progress at present. The most promising sites for groundwater exploration were demarcated [56]. The climate is classified as dry-Mediterranean, with relatively cold winters and hot summers. The canyon shape tributaries close to the Dead Sea are arid. Average annual rainfall ranges from $346 \mathrm{~mm}$ at Madaba (a few kilometers to the northwest of the catchment) to $282 \mathrm{~mm}$ at Dhiban, and $266 \mathrm{~mm}$ at the W.Wala weather station. Rainfall is concentrated in October and March. Large seasonal variations in temperature are evident, where daily temperatures range from a maximum $\approx 40^{\circ} \mathrm{C}$ in August to a minimum of $-5^{\circ} \mathrm{C}$ in January. Rainfed cultivation of cereals (wheat and barley) is practiced in $38 \%$ of the total area of the catchment, and open rangeland constitutes $47 \%$ of the total area. Some $7 \%$ of the total area is urban [56].

\section{Materials and Methods}

\subsection{Extraction of Morphometric Parameters}

The bifurcation ratio $\left(\boldsymbol{R}_{b}\right)$ is defined as the ratio of streams number of a given order to the number of the streams of the next higher order [57], and it is computed by:

$$
R_{b}=N_{u} / N_{u}+1 \text { where }
$$

$$
\begin{aligned}
& N_{u}=\text { total number of stream segments of order " } u \text { ", } \\
& N_{u}+1=\text { no. of segments of the next higher order. }
\end{aligned}
$$


Bifurcation ratio is elaborated as an index of relief and dissection. $\mathrm{Rb}$ values of drainage basins vary from 2 for flat/undulating or rolling terrain, to 6 for catchment where drainage network is distorted heavily by geological structure [57] [58] [59]. High $\mathrm{Rb}$ values indicate high overland flow and an early hydrograph peak with a high potential of susceptibility to flash flooding during exceptionally heavy rainstorms [60], which in turn increase soil erosion rates and sediment discharge in the main channel.

Drainage density $\left(D_{d}\right)$ is computed as the total length of streams in a drainage basin per unit area [57] [61] [62], or

$$
D_{d}=L_{u} / A
$$

$A=$ the basin area,

$L_{u}=$ is the total stream length.

$D_{d}$ is a measure of topographic dissection and runoff potential of the drainage basin. High $D_{d}$ value denotes high runoff, a quick stream response, and in turn, a low infiltration rate. Whereas low drainage density of a catchment implies low runoff and high infiltration [63].

Stream frequency $\left(F_{s}\right)$ is defined as the ratio of the total number of streams $\left(N_{u}\right)$ of all orders in a catchment to the watershed area $(A)$ [57]. It is expressed by the following equation:

$$
F_{s}=N_{u} / A .
$$

$F_{s}$ are positively correlated with $D_{d}$ values of a watershed. Low $F_{s}$ values indicates a relatively low infiltration rate of surface water, and thus the ground water potential is relatively low [64]. High stream frequency denotes more infiltration, and thus high groundwater potential.

Texture ratio $\left(T_{r}\right) T_{r}$ is refers to the ratio of the total number of streams of the first order (N1) to the perimeter of the drainage basin. It is considered a highly significant parameter in drainage basin morphometry. $T_{r}$ variable relies on slope materials and lithology, infiltration capacity and topographic relief [65]. Texture ratio is determined by:

$$
\operatorname{Tr}=N_{u} / P \text { where, }
$$

$N_{u}=$ the total no. of streams of all orders,

$P=$ perimeter $(\mathrm{km})$.

Length of overland flow $\left(L_{o}\right)$ is determined by the equation:

$$
L_{o}=H / L_{b} \text {, where }
$$

$H=$ basin $\operatorname{relief}\left(B_{h}\right) \mathrm{m}$,

$L_{b}=$ basin length $(\mathrm{km})$.

$L_{o}$ is the length of water over the ground before it is concentrated into definite stream channels [57]. $L_{o}$ parameter is one of the most significant independent variables affecting both hydrologic and hydrographic development of drainage basins. This parameter is related inversely to the average slope of the channel and is equivalent to a large extent to the length of sheet flow [57]. 
Form factor $\left(\boldsymbol{R}_{\boldsymbol{f}}\right)$ is calculated according to Horton [57]:

$$
R_{f}=A / L_{b^{2}} .
$$

$R_{f}$ refers to the ratio of the area of drainage basin to the square of the basin length [58]. Higher values of form factor denote a more circular shape of a catchment, while smaller $R_{f}$ values $(<0.45)$ imply that the basin is elongated in shape.

Shape factor $\left(\boldsymbol{B}_{s}\right)$ represent the ratio of the square of the basin length to the area of the basin, or

$$
B_{s}=L_{b^{2}} / A .
$$

Shape factor provides a conception regarding the circular character of the catchment. The greater the circular character, the greater the fast response of watersheds following an intense heavy rainstorm [66].

Elongation ratio $\left(\boldsymbol{R}_{e}\right)$ is defined by Schumm [67] according to the following equation:

$$
R_{e}=1.128 \sqrt{A / L_{b}} .
$$

Low values of $R_{e}$ denote that the catchment is more elongated. Where the $R_{e}$ value approaches 1.0, the shape of the watershed becomes a circular shape [67].

Compactness coefficient $\left(C_{c}\right)$ is developed by Gravelius [68], and defined as the ratio of perimeter of a watershed to circumference of the circle area, which is equal to the area of the watershed. $C_{c}$ is computed according to the following equation:

$$
C_{c}=\frac{P}{2 \sqrt{\pi A}} \text { where }
$$

$P=$ perimeter of the basin $(\mathrm{km})$,

$A=$ area of the basin $\left(\mathrm{km}^{2}\right)$.

When $C_{c}$ value is 1 , it indicates that the watershed is a perfect circle. If the $C_{c}$ value is 1.28 , the basin is more square shaped, while the basin is considered highly elongated, when the $C_{c}$ value $>3.0$ [69].

The circularity ratio $\left(\boldsymbol{R}_{c}\right)$ of a catchment is calculated according to:

$$
R_{c}=4 \pi \times A / P^{2} \text {, where, }
$$

$(A)$ is the basin area, and $(P)$ is the perimeter [70]. If $R_{c}$ is close to 1, the shape of a catchment is circular. Low, medium, and high values of $R_{c}$ indicate young, mature, and old stages of geomorphic development of the catchment respectively.

\subsection{Tools, Data Used, and Statistical Techniques}

Morphometric analysis for prioritization of the 23 fourth-order sub-basins related to W.Wala watershed was conducting using topo sheets, ASTER DEM and Arc GIS software. Topographic maps of scale 1:50,000 were acquired from the Royal Jordanian National Geographic Centre (Amman). They were scanned, geo-referenced, and converted to a zone $36 \mathrm{~N}$ projection system using Arc GIS 
10.1, and the associated packages. The W.Wala watershed and the 23 sub-basins were delineated using the topo sheets. Then ASTER DEM (30 m resolution) was utilized to extract the drainage networks using the Arc Hydro tool. Stream order was designated using the stream ordering system developed by Horton [57] and elaborated by Strahler [58]. The W.Wala watershed is classified as a sixth-order drainage basin (Figure 3). Fifteen morphometric parameters were calculated using DEM, GIS, and the mathematical equations developed elsewhere [41] [57] [59]. Five basic parameters were derived to illustrate the morphometric characteristics of the 23 sub-basins, Area $(A)$, Basin length $\left(L_{b}\right)$, Perimeter $(P)$, Stream order $(u)$, and Stream Length $\left(L_{u}\right)$. Furthermore, five linear parameters, and five shape parameters were considered in prioritization of the 23 sub-basins based on morphometric analysis as exemplified earlier. These are: Bifurcation ratio $\left(R_{b}\right)$, Drainage density $\left(D_{d}\right)$, Stream frequency $\left(F_{s}\right)$, Texture ratio $\left(T_{r}\right)$, and Length of overland flow $\left(L_{o}\right)$. Moreover, the five shape parameters used in this research are: Shape factor $\left(B_{s}\right)$, Form factor $\left(R_{f}\right)$, Circularity ratio $\left(R_{c}\right)$, Elongation ratio $\left(R_{e}\right)$, and compactness coefficient $\left(C_{c}\right)$. All morphometric parameters were measured directly from the DEM using GIS software. A land use/land cover map (Figure 4) was compiled using ERDAS IMAGINE 2015 (v.15), LANDSAT 8 (July 2017), and supervised classification. The Maximum likelihood Method of classification techniques was employed to classify land use/cover, based on the classification system proposed by Anderson et al. [71]. A soil map (Figure 5) was digitized from the 1994 National soil survey maps and reports pertaining to the $\mathrm{Na}$ tional soil and land use maps [72]. A slope categories map was generated using ASTER DEM (Figure 5). A remarkable variation exists in slope categories. Slope categories of $0^{\circ}-5^{\circ}, 5^{\circ}-10^{\circ}$, and $10^{\circ}-15^{\circ}$ dominated the eastern part of

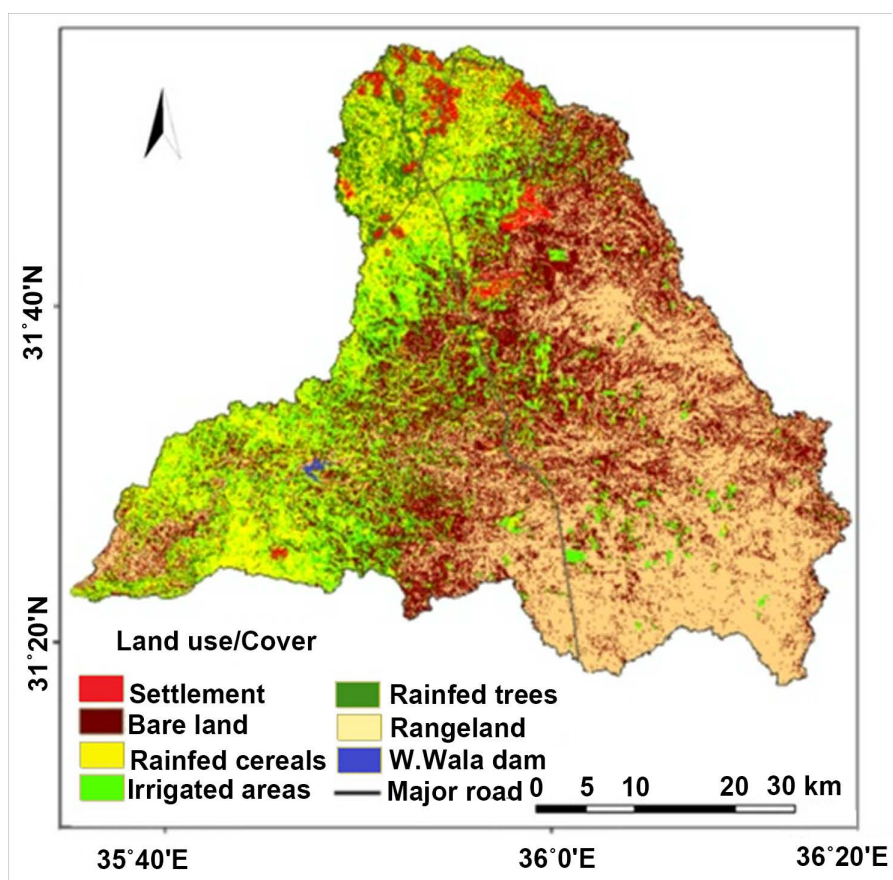

Figure 4. Land use/land cover. 


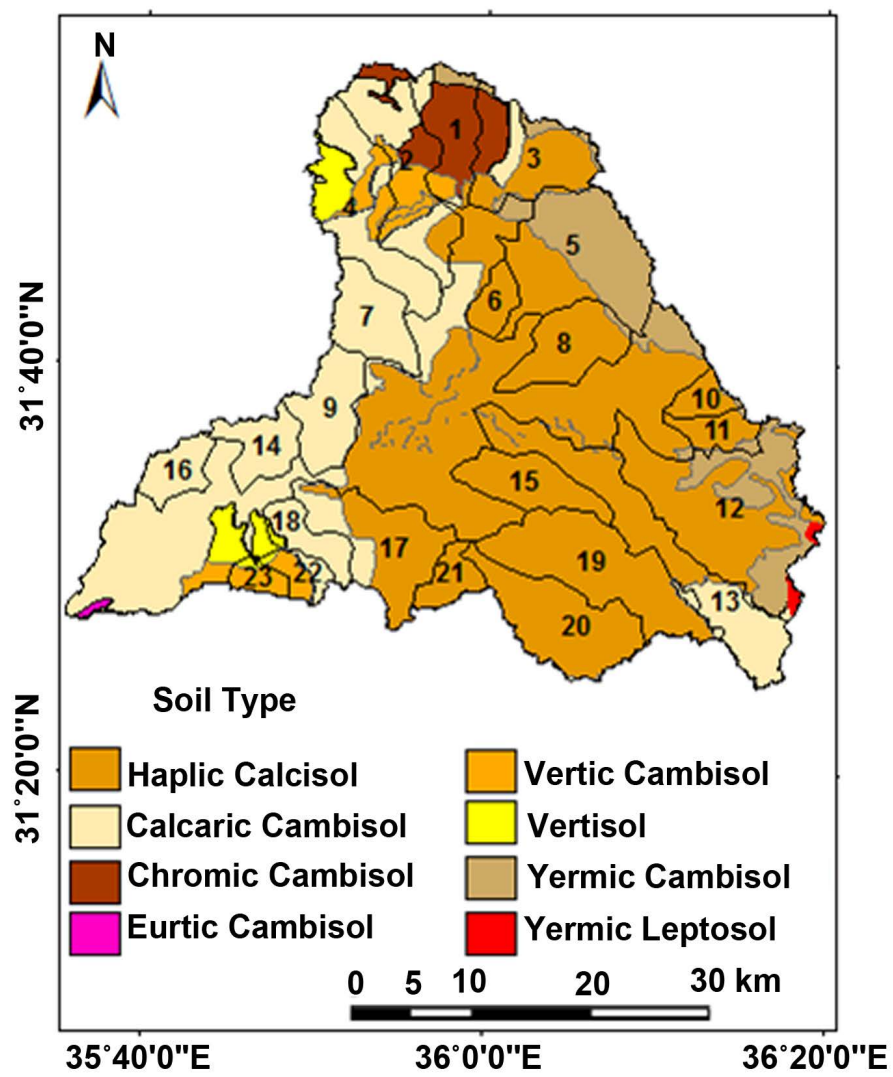

Figure 5. Soils of W.Wala.

the catchment. Whereas, slope categories $15^{\circ}-20^{\circ}, 20^{\circ}-30^{\circ}$, and $>30^{\circ}$ stand out in the western part, with the presence of cliffs $\left(>45^{\circ}\right)$ along the canyon tributaries downstream. The development of an efficient and cost, effective GIS and remote sensing techniques enables researchers to extract, measure, compute and process precisely basic, linear, shape, and relief morphometric parameters of drainage basins. Moreover, the availability of free access Digital Elevation Models (i.e., STRM and ASTER DEMs) with a reasonable resolution $(90 \mathrm{~m}$ and $30 \mathrm{~m}$ respectively) have improved the quantitative analysis approach of drainage networks, and morphometric mapping, thus, expanding the application of morphometric analysis to other fields of research. Discriminant Analysis (DA) was employed to test statistically the validity of priority groups of sub-basins generated based on morphometric analysis, and to determine if they are significantly different from each other, and to help in explaining regional spatial difference among the fourth-order sub-watersheds in term of prioritization. Through this technique, each sub-watershed can be related to a set of discriminant functions by calculating its "scores" on those functions. The mean value of these scores, on each discriminant function, can be calculated for each priority class. The mean values are then utilized to test if the priority classes are significantly different from each other, or in other words, if the resultant priority classes are accepted or not. 


\section{Results and Discussion}

\subsection{Morphometric Analysis}

\subsubsection{Basic Parameters}

The basin area $(A)$ is a principal component in hydrological processes [73]. In this regard, Chorley et al. [74] argued that the maximum discharge of flood per unit area is inversely related to the size of the drainage basin. The total area of Wadi Wala is $2063.6 \mathrm{~km}^{2}$, and for the 23 sub-watersheds, it ranges from $18 \mathrm{~km}^{2}$ to $184.99 \mathrm{~km}^{2}$. The basin length $\left(L_{b}\right)$ corresponds to the maximum length of the watershed and sub-basins measured parallel to the main drainage line. The length of the W.Wala basin is $88.8 \mathrm{~km}$, whereas the lengths of the sub-basins vary from 5.423 to $38.186 \mathrm{~km}$. The perimeter $(\mathrm{P})$ of W.Wala is $403.9 \mathrm{~km}$, and the perimeters of the sub-basins vary from 5.423 to 38.186 (Table 1). Sub-basins no.23 represents the shortest, but with the longest perimeter, while sub-watershed no. 13 is the longest, but with the highest perimeter. In terms of area, sub-basin 12 is the largest, and sub-basin 10 is the smallest. Nevertheless, the greater area sub-basins and the longest are located close to the northwestern, southeastern, and the eastern borders of the main catchment. Whereas the shortest in length and smallest in area are located in the rejuvenated belt due to the dominance of steep slopes and topographic dissection. The W.Wala watershed is classified as a sixth-order basin, while all the delineated 23 sub-basins are of fourth-order. Stream length $\left(L_{u}\right)$ is measured from the origin of a stream to the drainage divide. The total stream length of W.Wala is $2839.2 \mathrm{~km}$, and the first-order streams represent $49.9 \%$ of the total stream length. The following linear and shape morphometric parameters will be discussed with reference to their significance to morphological and hydrological properties, and implications for soil and water conservation.

\subsubsection{Linear Parameters}

The morphometric parameters are: bifurcation ratio $\left(R_{b}\right)$, drainage density $\left(D_{d}\right)$, stream frequency $\left(F_{s}\right)$, texture ratio $\left(T_{r}\right)$, and length of overland flow $\left(L_{o}\right)$.

\section{Bifurcation ratio $\left(R_{b}\right)$}

The bifurcation ratio is developed by Horton [57] as a morphological index for relief and dissection. The $R_{b}$ value for W.Wala is 4.5 , and for the 23 sub-basins varies from 2 to 7 (Table 1), with an average of 4.55 . High $R_{b}$ values demonstrate that most of the sub-basins are crucially affected by tectonics and structural disturbances caused by the W.Wala fault, the W. Az-Za'faran fault, the W. ZerqaMa'an fault, and the W. Al-Falij fault, and the associated dense lineaments [75].

\section{Drainage density $\left(D_{d}\right)$}

Drainage density value for W.Wala watershed is 1.385 , and for the 23 sub-watersheds varies from 1.19 to 1.77 which indicates moderate to well-drained watersheds. Slight variation is seen in $D_{d}$ values between the upper sub-watersheds $(x=1.43)$, and the lower sub-watershed $(x=1.32)$ [75]. Higher drainage density in the upper reaches is probably attributed to the availability of rainfall, high relief, steep slopes, 
Table 1. Morphometric characteristics of the 23 sub-basins.

\begin{tabular}{|c|c|c|c|c|c|c|c|c|c|c|c|c|c|c|c|}
\hline \multirow[b]{2}{*}{ Sub-Basin } & \multicolumn{5}{|c|}{ Basic Parameters } & \multicolumn{5}{|c|}{ Linear Parameters } & \multicolumn{5}{|c|}{ Shape Parameters } \\
\hline & $L_{b}$ & $A$ & $P$ & $N_{U}$ & $L_{u}$ & $\boldsymbol{R}_{b}$ & $D_{d}$ & $F_{s}$ & $T_{r}$ & $L_{o}$ & $\boldsymbol{R}_{f}$ & $\boldsymbol{B}_{s}$ & $R_{e}$ & $C_{c}$ & $\boldsymbol{R}_{c}$ \\
\hline 1 & 13.122 & 54.089 & 47.677 & 60 & 67 & 3 & 1.239 & 1.109 & 1.374 & 0.619 & 0.314 & 3.20 & 0.632 & 3.67 & 0.299 \\
\hline 2 & 21.469 & 103.044 & 93.132 & 112 & 128.942 & 5 & 1.251 & 1.087 & 1.360 & 0.626 & 0.224 & 4.47 & 0.533 & 3.69 & 0.149 \\
\hline 3 & 13.163 & 86.633 & 60.930 & 93 & 123.803 & 4 & 1.429 & 1.073 & 1.534 & 0.715 & 0.500 & 2.00 & 0.798 & 5.18 & 0.294 \\
\hline 4 & 23.000 & 98.752 & 90.630 & 108 & 131.064 & 3 & 1.327 & 1.094 & 1.451 & 0.664 & 0.187 & 5.36 & 0.487 & 5.16 & 0.150 \\
\hline 5 & 16.930 & 130.193 & 91.249 & 160 & 184.59 & 7 & 1.418 & 1.229 & 1.742 & 0.709 & 0.454 & 2.20 & 0.760 & 3.48 & 0.248 \\
\hline 6 & 7.299 & 19.762 & 24.819 & 35 & 30.343 & 2 & 1.535 & 1.771 & 2.719 & 0.768 & 0.371 & 2.70 & 0.687 & 3.99 & 0.403 \\
\hline 7 & 12.791 & 50.750 & 43.834 & 54 & 69.036 & 3 & 1.360 & 1.064 & 1.447 & 0.680 & 0.310 & 3.22 & 0.628 & 4.08 & 0.332 \\
\hline 8 & 13.833 & 57.609 & 45.538 & 78 & 86.336 & 4 & 1.499 & 1.354 & 2.029 & 0.749 & 0.301 & 3.32 & 0.619 & 2.93 & 0.349 \\
\hline 9 & 12.017 & 53.685 & 51.830 & 58 & 72.798 & 2 & 1.356 & 1.080 & 1.465 & 0.678 & 0.372 & 2.70 & 0.688 & 2.85 & 0.251 \\
\hline 10 & 7.434 & 18.004 & 22.696 & 28 & 31.874 & 2 & 1.770 & 1.555 & 2.753 & 0.885 & 0.326 & 3.07 & 0.644 & 2.97 & 0.439 \\
\hline 11 & 10.033 & 24.710 & 33.959 & 34 & 39.081 & 2 & 1.582 & 1.376 & 2.176 & 0.791 & 0.245 & 4.07 & 0.559 & 3.88 & 0.269 \\
\hline 12 & 24.800 & 184.994 & 135.612 & 238 & 265.13 & 7 & 1.433 & 1.287 & 1.844 & 0.717 & 0.301 & 3.32 & 0.619 & 4.93 & 0.126 \\
\hline 13 & 38.186 & 125.855 & 153.578 & 150 & 170.386 & 4 & 1.354 & 1.192 & 1.614 & 0.677 & 0.086 & 11.85 & 0.331 & 4.36 & 0.067 \\
\hline 14 & 9.259 & 37.025 & 43.993 & 51 & 51.743 & 2 & 1.398 & 1.377 & 1.925 & 0.699 & 0.432 & 2.32 & 0.741 & 4.78 & 0.240 \\
\hline 15 & 16.538 & 48.561 & 55.576 & 70 & 64.845 & 2 & 1.335 & 1.442 & 1.925 & 0.668 & 0.178 & 5.63 & 0.475 & 5.29 & 0.198 \\
\hline 16 & 6.020 & 29.326 & 28.189 & 38 & 40.231 & 2 & 1.372 & 1.296 & 1.778 & 0.686 & 0.809 & 1.24 & 1.015 & 4.49 & 0.464 \\
\hline 17 & 18.792 & 87.159 & 81.599 & 99 & 112.191 & 3 & 1.287 & 1.136 & 1.462 & 0.644 & 0.247 & 4.05 & 0.560 & 7.72 & 0.164 \\
\hline 18 & 10.666 & 28.975 & 36.978 & 34 & 37.385 & 2 & 1.290 & 1.173 & 1.514 & 0.645 & 0.255 & 3.93 & 0.569 & 5.62 & 0.266 \\
\hline 19 & 25.015 & 118.546 & 102.057 & 139 & 175.885 & 5 & 1.484 & 1.173 & 1.740 & 0.741 & 0.189 & 5.27 & 0.491 & 3.01 & 0.143 \\
\hline 20 & 17.032 & 89.673 & 80.150 & 99 & 129.872 & 3 & 1.488 & 1.104 & 1.599 & 0.724 & 0.309 & 3.23 & 0.627 & 3.85 & 0.175 \\
\hline 21 & 7.479 & 21.347 & 35.725 & 34 & 29.788 & 2 & 1.395 & 1.593 & 2.222 & 0.698 & 0.382 & 2.62 & 0.697 & 3.39 & 0.210 \\
\hline 22 & 7.146 & 18.836 & 22.794 & 27 & 24.18 & 2 & 1.284 & 1.433 & 1.840 & 0.642 & 0.369 & 2.71 & 0.685 & 4.01 & 0.456 \\
\hline 23 & 5.423 & 12.116 & 17.590 & 17 & 14.402 & 2 & 1.189 & 1.403 & 1.668 & 0.594 & 0.412 & 2.43 & 0.724 & 3.14 & 0.492 \\
\hline
\end{tabular}

and overgrazed areas which resulted in greater runoff and thus, more erosion and surface drainage lines [76].

\section{Stream frequency $\left(F_{s}\right)$}

$F_{s}$ values are positively correlated with drainage density of all sub-basins. Therefore, any increase in stream population led to an increase in $D_{d}$ value [77]. Low $D_{d}$ values indicate a low infiltration rate of surface water, thus, suggesting relatively low groundwater potential [64]. The lowest value of $F_{s}$ is observed in sub-basin 7 $\left(F_{s}=1.064\right)$, whereas the highest value is observed in sub-basin $6\left(F_{s}=1.771\right)$. High $F_{s}$ values are characteristic of areas with high density of lineaments associated with major faults, i.e., the W.Wala and W. Rumeil faults [56].

\section{Texture ratio $\left(T_{r}\right)$}

Texture ratio is considered an important factor in drainage basin morphome- 
try. The $T_{r}$ for W.Wala is 4.8 , and for the 23 sub-basins, it ranges from 1.36 (sub-basin no. 2) to 2.8 for sub-basin no. 10. $T_{r}$ values indicate that the watersheds are of high runoff.

\section{Length of overland flow $\left(L_{o}\right)$}

The length of overland flow is one of the most significant independent parameters affecting the hydrographic and hydrologic development of a drainage basin [57]. The length of overland flow for the 23 sub-basins varies from 0.594 (sub-basins no. 23) to 0.791 for sub-basin no. 11 .

\subsubsection{Shape Parameter}

\section{Form factor $\left(R_{f}\right)$}

Form factor is a dimensionless property and used as a quantitative expression of the shape of watersheds [45]. Catchments with high $R_{f}$ values experience high peak flow of short duration. By contrast, an elongated catchment with low form factor has a low peak flows of longer duration. The $R_{f}$ value for W.Wala is 0.286 , and for the 23 sub-basins it ranges from 0.086 (sub-basin no. 13), to 0.809 (sub-basin no. 16). Most of sub-watersheds have $R_{f}$ values varying from 0.3 to 0.5 , which indicates that these sub-basins are elongated and more elongated, shape is associated with low peak flow of longer duration, and thus, of less probability for severe flooding [39].

\section{Shape factor $\left(B_{s}\right)$}

The shape factor for the entire W.Wala is 3.821, whereas, the 23 sub-basins exhibit a range from 1.24 (sub-basin no. 16) to 11.58 (sub-basin no. 13), which implies that elongated shapes dominate most of the sub-basins.

\section{Elongation ratio $\left(R_{e}\right)$}

$\mathrm{R}_{\mathrm{e}}$ values close to 1.0 are characteristic of watersheds with low and simple relief, while values range from 0.6 to 0.8 representing catchments with high rugged relief and steep slopes. The elongation ratio for W.Wala catchment is 0.577 , while it ranges from 0.331 (sub-basin no. 13) to 1.0, where sub-basin no. 16 is the only circular basin.

\section{Compactness coefficient $\left(C_{c}\right)$}

The $C_{c}$ parameter is independent of size of the catchment and dependent mainly on slope. Low $i$ values imply more elongation and high erosion [57] [59]. The $C_{c}$ value for W.Wala watershed is 2.51 , whereas the $C_{c}$ values for the 23 sub-basins vary from 2.85 (sub-watershed no. 9) and 7.72 for sub-basin no. 17, which reflects high surface erosion.

\section{Circularity ratio $\left(R_{c}\right)$}

Circularity ratio is the most useful shape morphometric measure in correlation with stream discharge. $R_{c}$ is influenced by geology, morphology (relief and slope), climate, land use/land cover of the catchment [70]. The circularity ratio for W.Wala is 0.159 , whereas, the $R_{c}$ values for the 23 sub-basins range from 0.126 (sub-basin no. 12) to 0.492 (sub-basin no. 23). These values imply that W.Wala and the sub-basins are at the youth-age stage of geomorphic development, and they are elongated in shape. 


\subsection{Prioritization of Sub-Basins Based on Morphometric Analysis and Proposed Conservation Measures}

Recently, morphometric analysis was employed broadly to assess watersheds of different size (sub-watersheds, mini-watersheds, and micro watersheds) for soil and water conservation [31] [34] [36] [37] [38] [41] [42] [44] [45]. The linear and shape morphometric parameters termed "erosion risk parameters" [31] [41] were utilized for prioritization of the 23 sub-basins connected with W.Wala, and designated 1 - 23 (Figure 6). The linear parameters include(a): bifurcation ratio $\left(R_{b}\right)$, drainage density $\left(D_{d}\right)$, stream frequency $\left(F_{s}\right)$, texture ratio $\left(T_{r}\right)$, and length of overland flow $\left(L_{o}\right)$; and the shape parameters include (6): form factor $\left(R_{f}\right)$, shape factor $\left(B_{s}\right)$, elongation ratio $\left(R_{e}\right)$, compactness coefficient $\left(C_{c}\right)$, and circularity ratio $\left(R_{c}\right)$. Based on the range of computed compound parameter $\left(C_{p}\right)$ values (Table 2), the 23 sub-basins of W.Wala were classified into three priority groups:

1) High priority (3 - 4),

2) Moderate Priority ( 4 - 5),

3) Low priority (5 - 6).

Using the Arc GIS tool, the spatial distribution of the 23 sub-basins groups based on the compound parameter values $(\mathrm{Cp})$ was generated. Figure 7 illustrates the priority classes of sub-basins for soil and water conservation.

Prioritization was successful in classifying the 23 sub-watersheds into three groups of high, moderate, and low priority for soil conservation measures. The three groups were determined mainly by land use/land cover, and historical exploitation of soil resources. Other factors such as morphology (relief and slope),

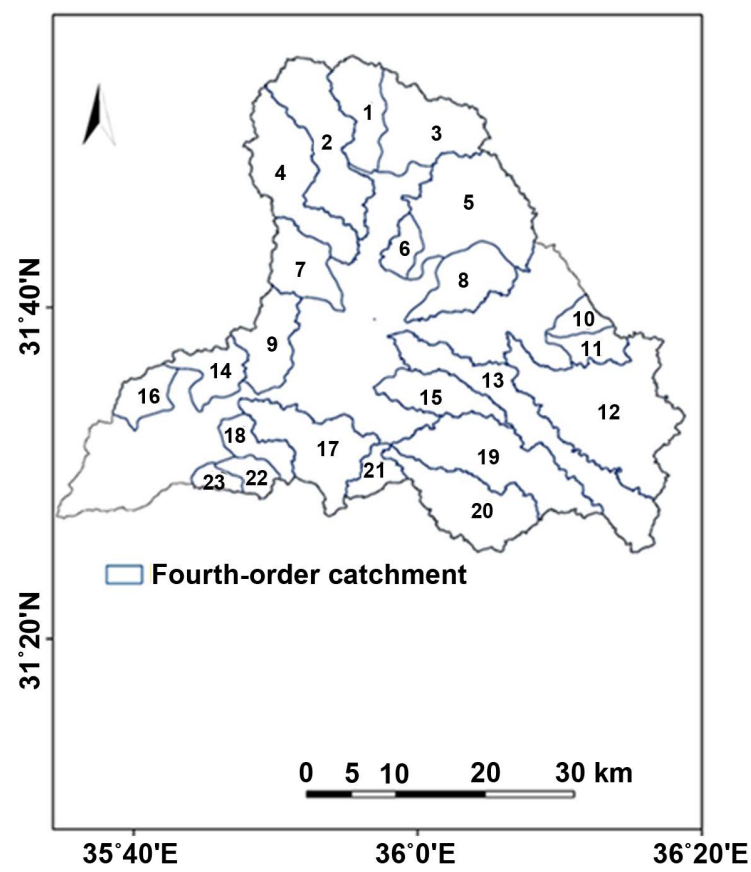

Figure 6. Fourth-order sub-basins. 


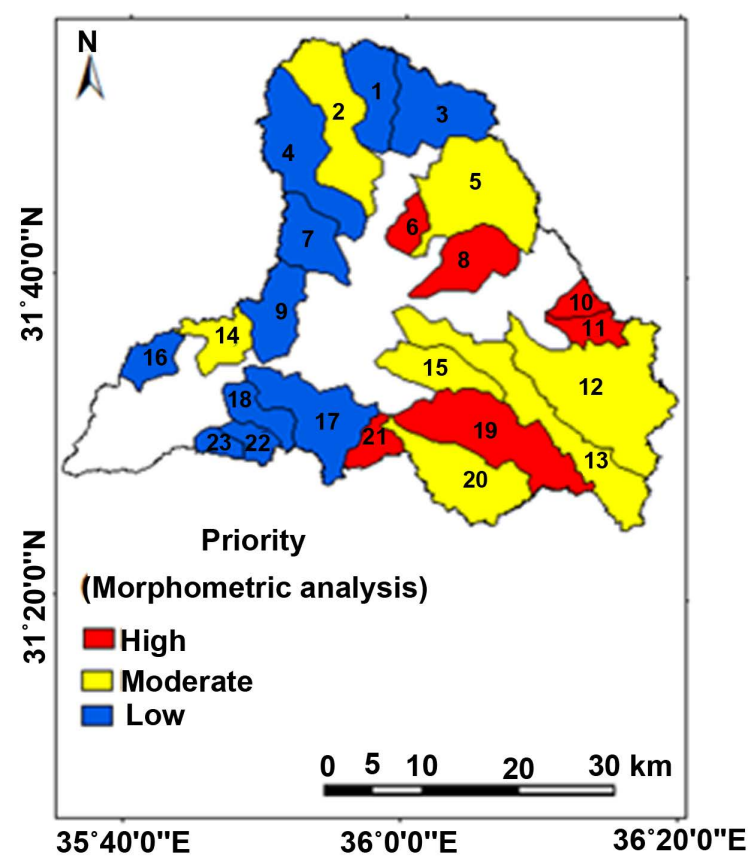

Figure 7. Priority of the 23 sub-basins based on morphometric analysis.

and geomorphic agents, i.e., rejuvenation are also influential, although its impact varies spatially from west to east over the W.Wala catchment. The long periods of human intervention, land use abuse, and the destruction of vegetation cover was decisive in maximizing soil erosion over the sub-basins which traditionally have been utilized for rainfed farming, or rangeland transformed to rainfed cultivation since the 1950s in the eastern part of the watershed. Spatially, sub-watersheds are characterized by high priority and are found in the rainfed areas, which occupy a substantial part of the watershed, over-grazed range land, bare land, and the western rejuvenated belt of the watershed.

Accordingly, the highest priority reveals the great degree of erosion risk associated with particular sub-basins, and thus, represents a potential area for adaptation soil and water conservation measures [38]. Out of the 23 sub-basins of W.Wala, 6 sub-basins ( $26 \%$ of the total) (sub-basins nos. $6,8,10,11,19,21$ ) are classified as high priority (Figure 7 ). Eight sub-basins (34.8\% of total) (sub-basins nos. 2, $5,12,13,14,15,16,29)$ come under moderate priority (Figure 7) for soil and water conservation. It is obvious that $62 \%$ of the sub-basins are grouped under high and moderate priority for soil and water conservation. Eleven of these sub-basins are located at the eastern-southeastern part of W.Wala watershed, and three sub-basins are located at the northwestern part of the watershed (Figure 7). Their distribution is found in accordance with the land use/land cover pattern, especially overgrazed rangeland, and bare lands where the vegetation cover has been highly degraded (Figure 4).

These sub-basins are characterized by highest relief over the entire watershed $(800>900 \mathrm{~m}$ a.s.l), where slope categories of $0-5,5-10$, and $10-15$ are 
Table 2. Calculation of compound parameters and prioritized ranks based on morphometric analysis.

\begin{tabular}{|c|c|c|c|c|c|c|c|c|c|c|c|c|}
\hline $\begin{array}{c}\text { Sub-basin } \\
\text { no. }\end{array}$ & $R_{b}$ & $D_{d}$ & $F_{s}$ & $T_{r}$ & $L_{o}$ & $R_{f}$ & $B_{s}$ & $R_{e}$ & $C_{c}$ & $R_{c}$ & $C_{P}$ & \multirow[t]{2}{*}{ Priority } \\
\hline & & & & & & & & & & & Value & \\
\hline 1 & 4 & 9 & 8 & 8 & 4 & 5 & 4 & 4 & 3 & 5 & 5.4 & Low \\
\hline 2 & 2 & 9 & 7 & 8 & 4 & 4 & 6 & 3 & 3 & 2 & 4.8 & Moderate \\
\hline 3 & 3 & 5 & 10 & 6 & 3 & 8 & 2 & 5 & 6 & 5 & 5.3 & Low \\
\hline 4 & 4 & 7 & 10 & 7 & 4 & 3 & 7 & 2 & 6 & 2 & 5.2 & Low \\
\hline 5 & 1 & 5 & 7 & 6 & 3 & 7 & 2 & 5 & 2 & 4 & 4.2 & Moderate \\
\hline 6 & 5 & 3 & 1 & 1 & 2 & 6 & 3 & 4 & 3 & 7 & 3.5 & High \\
\hline 7 & 4 & 6 & 10 & 11 & 4 & 5 & 4 & 4 & 4 & 6 & 5.8 & Low \\
\hline 8 & 3 & 4 & 6 & 2 & 3 & 5 & 4 & 4 & 1 & 6 & 3.8 & High \\
\hline 9 & 5 & 7 & 10 & 10 & 4 & 6 & 3 & 4 & 1 & 3 & 5.3 & Low \\
\hline 10 & 5 & 1 & 3 & 1 & 1 & 5 & 4 & 4 & 1 & 7 & 3.2 & High \\
\hline 11 & 5 & 2 & 4 & 2 & 2 & 4 & 6 & 3 & 3 & 5 & 3.6 & High \\
\hline 12 & 1 & 5 & 7 & 4 & 3 & 5 & 4 & 4 & 5 & 2 & 4 & Moderate \\
\hline 13 & 3 & 7 & 8 & 8 & 4 & 1 & 8 & 1 & 4 & 1 & 4.5 & Moderate \\
\hline 14 & 5 & 6 & 5 & 3 & 4 & 7 & 2 & 5 & 5 & 4 & 4.6 & Moderate \\
\hline 15 & 5 & 7 & 4 & 3 & 4 & 2 & 7 & 2 & 6 & 3 & 4.3 & Moderate \\
\hline 16 & 5 & 6 & 7 & 5 & 4 & 3 & 1 & 6 & 4 & 8 & 4.9 & Moderate \\
\hline 17 & 4 & 8 & 6 & 10 & 5 & 4 & 6 & 3 & 8 & 3 & 5.7 & Low \\
\hline 18 & 5 & 8 & 8 & 9 & 5 & 4 & 5 & 3 & 7 & 5 & 5.9 & Low \\
\hline 19 & 2 & 4 & 8 & 4 & 2 & 3 & 7 & 2 & 2 & 2 & 3.6 & High \\
\hline 20 & 4 & 5 & 9 & 8 & 3 & 5 & 4 & 4 & 3 & 3 & 4.8 & Moderate \\
\hline 21 & 5 & 6 & 2 & 2 & 4 & 6 & 3 & 4 & 3 & 4 & 3.9 & High \\
\hline 22 & 5 & 8 & 4 & 4 & 5 & 6 & 3 & 4 & 4 & 7 & 5 & Low \\
\hline 23 & 5 & 9 & 4 & 7 & 6 & 7 & 2 & 5 & 2 & 8 & 5.5 & Low \\
\hline
\end{tabular}

predominant. The destruction of vegetation cover, caused severe soil erosion since the Neolithic and Chalcolithic periods. Indicators of soil erosion and the existence of agricultural stone terraces, imply that the highlands of rainfed farming (including W.Wala) experienced severe soil erosion at least since the Nabatean period, some 3000 years ago [2]. High relief ratio $\left(R_{r}\right)$ has also been recorded for several sub-basins pertaining to high and moderate priority for soil and water conservation (i.e., sub-basins nos. 6, 10, 11, and 16) which can be considered an essential factor in the assessment of soil erosion and sediment load in W.Wala watershed. Furthermore, high hypsometric integral (HI) values for sub-basins (e.g. nos. 2, 5, 6, 8, 12) classified as high and moderate priority vary from $70 \%$ to $89 \%$, which indicate that these drainage basins are influenced by rejuvenation processes, and are considered at the youth-age stage of geomorphic 
development. Consequently, surface erosion rates are considerably high [75].

Nine sub-basins (39.2\% of the total) (sub-basins nos. 1, 3, 4, 7, 9, 17, 18, 22, and 23) are assigned to be of low priority for soil and water conservation. Three sub-watersheds out of nine consist mainly of wide and flat, undulating table lands overlooking the deep canyons downstream which occupied the rejuvenated belt. Other sub-watersheds (nos. 9, 7, 4, 3, and 1) extend to the northern/northeast part of W.Wala watershed.

The nine sub-watersheds constitute a major part of the rainfed agricultural region of Jordan, where the cultivation of wheat and barley is practiced over these sub-watersheds. Here, the average annual rainfall varies from $250 \mathrm{~mm}$ to 350 $\mathrm{mm}$. Scattered irrigated agriculture based on groundwater wells is practiced over the sub-basins categorized as being of high and moderate priority for soil and water conservation. Irrigated farming is also practiced downstream of W.Wala (Al-Haidan area) based on extracting the water from the springs and Al-Haidan groundwater wells (Figure 8(a)). High soil erodibility of Calcaric Cambisol and Eurtic Cambisols soil type (Figure 5), steep slopes $\left(14^{\circ}-20^{\circ}\right)$, poor conservation measures and degraded vegetation cover accelerates soil erosion, and exposed the sub-watersheds to high rates of soil erosion loss. However, the transformation of vast areas since the 1990s from rangeland into farming practice, and the expansion of rainfed "mixed farming" towards the marginal areas (Figure 8(b)), accelerate soil erosion and have increase the susceptibility of soil erosion over these sub-watersheds although, they rank under low priority for soil and water conservation. The cultivated land with poor conservation measures exhibits a higher rate of soil erosion and decline in soil fertility. Consequently, all sub-basins ranked under high and moderate priority are vulnerable to soil erosion, thus, they should be prioritized for conservation. Even over the sub-basins with mixed rainfed farming areas, traditional up and down slope tillage without conservation measures (i.e., contouring and terracing) is common in W.Wala. Thus, priority must be given to the protection of sub-watersheds exposed to high soil erosion rates, in order to reduce runoff coefficient, increase infiltration rates and soil moisture in soil profile. Reduction in soil erosion loss has been verified recently by Al-Sheriadeh and Al-Hamdan [26] where they concluded that in the years 1987-1990; the estimated sediments yields were less than the actual yields in the Kink Talal Reservoir of the Zerqa River. They attributed this to the implementation of a soil conservation program launched by the government of Jordan, in cooperation with the German government. Further, Al-Alawi and, Abujamous [78] estimated the average annual sediment loss in Central Jordan (Salt area) at 78 ton $\cdot \mathrm{ha}^{-1} \cdot \mathrm{year}^{-1}$ before the construction of stone terraces. Twenty years later following construction and tree planting, the estimated average soil loss have been reduced considerably to an average of $33 \mathrm{ton} \cdot \mathrm{ha}^{-1} \cdot \mathrm{year}^{-1}$ (35.7\%). Such encouraging results emphasize the need to execute intensive soil conservation programs over the highland to reduce soil erosion rates, in accordance with enhancing practiced soil conservation techniques, and to modify RUSLE parameters (i.e., C, P, and LS factors which are considered key factors in soil 


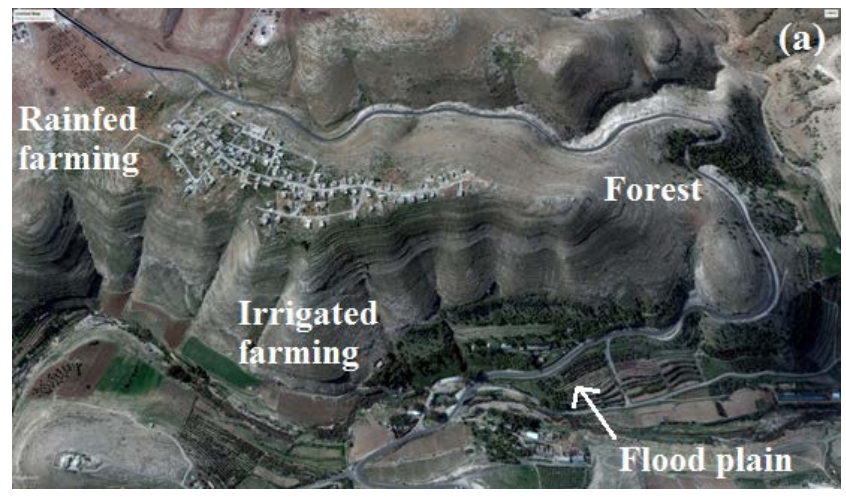

(a)

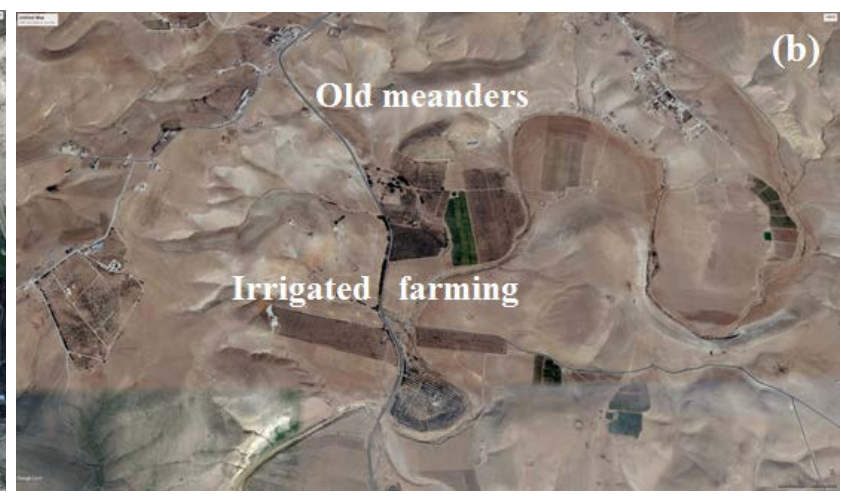

(b)

Figure 8. Irrigated farming (W.Wala flood plain) (a), rainfed cultivation on the summits, and pumping well irrigated farming (b). Source: Google Earth bro 1/1/2017.

erosion). It has been argued that RUSLE parameters can be modified significantly through altering farmers environmental practices [72] with the support of local governments. Slope length and steepness factor (LS), the conservation practice factor $(\mathrm{P})$, and the cover and management factor $(\mathrm{C})$, can be improved noticeably to reduce soil erosion loss and to conserve water in soil on the farm to maintain crop productivity. The LS factor can be modified mainly through the construction of what is locally termed mastaba, or contour stone terraces associated with tree planting on slopes ranging from $5^{\circ}-25^{\circ}$. Stone terraces should be aligned in long rows following the contours at various intervals depending on length and steepness of slope. On steep slopes $\left(>25^{\circ}\right)$ with a shortage of stones, bench terraces are more appropriate [79] [80]. Terrace farming in the W.Wala highlands has been practiced since some 3000 years ago [2]. The construction of check dams across the gullies ( $1-3 \mathrm{~m}$ of depth) can decrease runoff coefficient and soil erosion rates under different land utilization [81]. Structural soil conservation measures can be applied on gentle slopes $\left(0^{\circ}-5^{\circ}, 5^{\circ}-10^{\circ}\right)$, and moderate to steep slopes $\left(10^{\circ}-15^{\circ}, 15^{\circ}-20^{\circ}\right)$ characterize the sub-watersheds of high priority for soil conservation measures (sub-basins nos. 6, 8, 19, and 21), and sub-basins with moderate priority (sub-basins nos. 2, 20,14, 15, and 16) which are considered of high soil erosion rates, and soil loss-prone areas. It is more appropriate to integrate structural conservation measures with technology improving farming practice (i.e., rotation and contour ploughing) of rainfed cultivation to reduce soil erosion, and to enhance soil moisture in the soil profile. Such recommendations can be applied almost to all sub-basins categorized as of high, moderate, and low priority. The expansion of rainfed farming on rangeland and steep slopes $\left(>20^{\circ}\right)$ since the 1950s, has stimulated an increase in studies showing that the presence of rock fragments on the surface were highly effective in reducing soil erosion loss. The presence of stone cobbles and fragments of different size at the soil surface at $5 \%$ to $15 \%$ coverage, caused a momentous reduction in runoff by an average of $17 \%$ and $30 \%$ respectively. The corresponding reductions in soil loss for both stone streamlets were as large as 35\% and $53 \%$ respectively [80]. If plantation of trees is accompanied by stone coverage prac- 
tice, it will decrease soil loss, and increase infiltration rate and soil moisture. Rehabilitation of vegetation cover through planting trees of drought-resistance species is highly recommended to improve the grazing potential of the marginal areas of the entire watershed.

\subsection{Validation of Priority Classes: Discriminant Analysis (DA)}

The validity of the three priority classes determined through morphometric analysis, and represent the 23 sub-basins was tested using DA. The intention is to test the hypothesis that there is a significant difference between the priority classes obtained earlier, and if this hypothesis is accepted, to establish a system of coordinate axes which discriminate between the recognized priority groups. With reference to the three classes, it is obvious that there is a significant difference between low priority class, moderate class, and high priority class, with a noticeable concentration of high and moderate priority classes in the eastern part of W.Wala watershed. That is; in accordance with the deteriorated rangeland, bare land, and degraded vegetation cover as clarified in this part of the watershed earlier. Soil resources have been exhausted here over the last 3000 years, with prominent shortage of conservation measures. Statistical testing using Discriminant Analysis was performed on a data matrix representing the three priority groups (i.e. 6 $\times 11,8 \times 11$, and $9 \times 11$ ) with the associated ranking values and including the $C_{p}$ scores. The F test of Wilks Lambda obtained is F ratio is 45.7 with the degrees of freedom $\mathrm{V} 1=2$ and $\mathrm{V} 2=20$. Referring to the table of percentage points of the F-distribution, with V1 $=2$ and V2 $=20$, it is found that at 99.9 percent of confidence, the tabulated value is 9.95 , which is significantly exceeded by the computed $\mathrm{F}$ ratio value (45.7). Consequently, there is a high significant difference between each of the priority classes (high, moderate, and low), and the three priority groups are highly separated and distinct. Moreover, 100 percent of the difference between the three priority groups is attributed to discriminant function 1 (81.7 percent) and discriminant function 2 (18.3 percent). It was also revealed that discriminant function 1 is positively correlated with $C_{p}, T_{\mathrm{r}}, D_{\phi} L_{o}, F_{s}$, and $C_{c}$ parameters. By contrast discriminant function 2 is positively correlated with $B_{s}$, and $R_{e}$ parameters. The scores of each sub-basin of the three priority groups on the discriminant functions 1 and 2 were plotted in Figure 9. The plot displays highly separated and distinct priority groups. With reference to the present findings, it can be concluded that prioritization based on morphometric analysis is proven to be statistically valid, consistent and reliable, and of high capacity using the GIS platform. The potential of morphometric analysis method as elaborated by the pioneers, i.e. [31] [36] [41] [42] [81] is proven to be capable for prioritization research.

\section{Conclusions}

Soil erosion by water has seriously threatened rainfed farming over most of the highlands of W.Wala catchment. Further, soil erosion has also increased sediment supply to the W.Wala dam especially during exceptionally heavy rainstorms. 


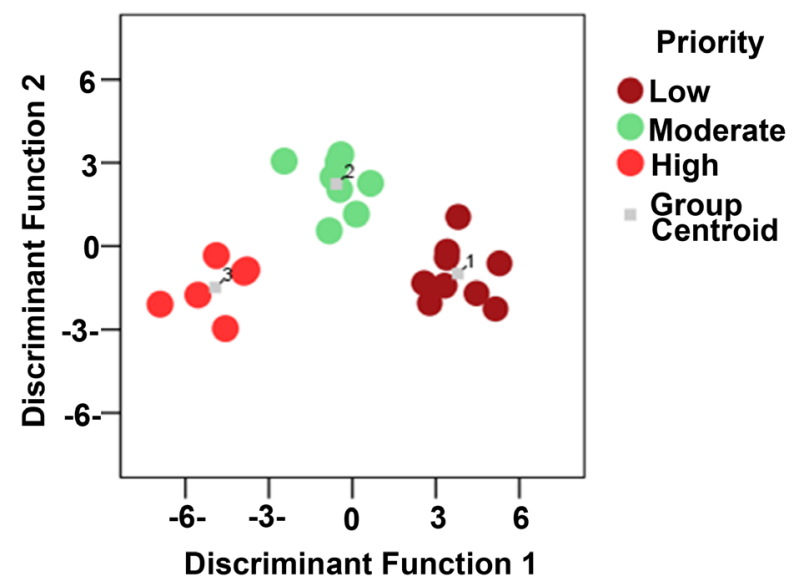

Figure 9. Results of discriminant functions 1 and 2 grouping: the three priority classes are completely separated and distinct.

Consequently, all sub-watersheds ranked under high and moderate priority in the present study, should be prioritized for soil conservation measures in order to maintain future farming sustainability. Integrated GIS and remote sensing, and morphometric analysis of linear and shape parameters, were employed to prioritize the 23 sub-basins, and then to prescribe efficient conservation measures especially for sub-basins subjected to rainfed farming.

The results of prioritization based on $\mathrm{Cp}$ values, indicate that sub-watershed no. 10 has been ranked 1 with the lowest compound parameter (Cp) at 3.2; while sub-basin no. 6 is ranked as the second with compound parameter at 3.5, and sub-basin no. 21 is ranked third, and all of them are with high priority (Figure 7). By contrast, sub-basins nos. 12, 5, and 15 are ranked as fourth, fifth and sixth with compound parameters at 4.0, 4.2, and 4.3 respectively and with moderate priority. All sub-basins with compound parameters equal or greater than 5 are ranked as low priority (Figure 7). All these sub-watersheds experienced historically severe soil erosion rates, and deterioration of natural vegetation. Information on land use/land cover, slope and soil types was utilized to help in recommending proper soil and water conservation structures. The suggested soil conservation measures take into account the existing and use/land cover, i.e., rainfed cultivation, irrigated farming, soils, rangeland, and slope categories $(0-25)$ connecting to each sub-basin. However, soil and water conservation measures were recommended in accordance with the priority ascribed so as to minimize the adverse effect on environmental resources. Expected benefits of improving and expanding soil conservation measures over sub-watersheds ranked as high and moderate priority (where rainfed farming is dominant) are illustrated in the following: control of soil erosion over sub-watersheds experienced high soil erosion loss to preserve the soil from future erosion; there was a reduction in sediment yield production to control sedimentation in W.Wala dam; and reduced peak flows across these sub-watersheds and the entire W.Wala catchment. The utilization of remote sensing and techniques verify the efficiency of this technology in priori- 
tization of W.Wala sub-basins, and prove the capacity of morphometric parameters in prioritization analysis for the highland watersheds within a GIS environment. Furthermore, the limitations of morphometric analysis method were examined, and the validity of prioritization was tested statistically using Discriminant Analysis. The results revealed that the three priority classes are significantly different from each other. Thus prioritization based on morphometric analysis method is accepted. The present results are intended to help decision-makers to recognize priority sub-basins which need immediate adaptation of appropriate conservation measures, and land management practices. In conclusion, the findings of present research indicate that prioritization based on morphometric analysis is proven to be statistically valid, consistent and reliable, and of high capacity using the GIS platform. Accordingly, the morphometric analysis method is highly recommended for prioritization research.

\section{References}

[1] Christopherson, G. and Guertin, D. (1995) Soil Erosion, Agricultural Intensification, and Iron Age Settlement in the Region of Tall El-Umeiri. Annual Meeting of American School of Oriental Research, Philadelphia, 19 November 1995.

[2] Cordova, C.E. (2000) Geomorphological Evidence of Intense Prehistoric Soil Erosion in the Highlands of Central Jordan. Physical Geography, 21, 538-567.

[3] Natural Resources Authority (1965) Soil Erosion in the East Ghor Region, Amman.

[4] McDonald Partners and Hunting Technical Services Ltd. (1965) East Bank Water Resources Summary Report. Central Water Authority, Amman.

[5] FAO, UNEP and UNECO (1979) A Provisional Methodology for Soil Degradation Assessment. FAO, Rome.

[6] Battikhi, A. and Arabiat, S. (1983) Constraints to the Successful Application of Modern Technology for Soil Conservation in Jordan: Environmental Features and Extent of Erosion. Dirasat, 10, 129-143.

[7] Willimott, S.G., Gilchrist-Shirlaw, D.W., Smith, R.A. and Virck, B.P (1963) The WadiHasa Survey, Jordan. Unpublished Report, Department of Geography, University of Durham, Durham.

[8] Atknson, K., Beaumont, P., Bowen-Jones, H., Fisher, W.B. and Gilchrist, D.W. (1967) Soil Conservation Survey of Wadi Shueib and Wadi Kufrein, Jordan. Unpublished Report, Department of Geography, University of Durham, Durham.

[9] Beaumont, P. and Atkinson, K. (1969) Soil Erosion and Conservation in Northern Jordan. Journal of Soil and Water Conservation, 24, 144-147.

[10] Central Water Authority (1966) Hydrological Division. Flood in Southern Jordan on 11 March 1966, Amman.

[11] Schick, A. (1971) A Desert Flood: Physical Characteristics, Effect on Man, Geomorphic Significance, Human Adaptation-A Case Study in the Southern Area a Watershed. Jerusalem Studies in Geography, 2, 91-155.

[12] Farhan, Y. and Anbar, A. (2014) Fragile Landscape: Impact and Consequences of May 2014 Flash Flood Disaster in the Aqaba Area, Southern Jordan. Research Journal of Environmental and Earth Sciences, 6, 451-465.

[13] Farhan, Y. (1986) Landslides in Central Jordan with Special Reference to the March 1983 Rainstorm. Singapore Journal of Tropical Geography, 7, 80-97. 
https://doi.org/10.1111/j.1467-9493.1986.tb00174.x

[14] Farhan, Y. (1999) Geomorphic Impacts of Highway Construction, Their Causes and Remedies: A Case Study from Aqaba, Southern Jordan. The Arab World Geographer, 2, 1-25.

[15] Farhan, Y. (2002) Slope Stability Problems in Central and Northern Jordan. The Arab World Geographer, 5, 265-290.

[16] Ananzeh, A. (1986) Sediment Yield of Wadi Kufranja Basin. M.A. Thesis, University of Jordan, Amman. (In Arabic)

[17] Dabbas, I. (1994) Soil Erosion Measurements in the Salt Area, Jordan. M.A. Thesis, University of Jordan. Amman. (In Arabic)

[18] Jawabreh, A. (1995) Soil Erosion Measurements in the Muwaqar Area, Jordan. M.A. Thesis, University of Jordan, Amman. (In Arabic)

[19] Al-Hamdan, A. (1996) Soil Erosion Measurements' in the Azraq Area, Jordan. M.A. Thesis, University of Jordan, Amman. (In Arabic)

[20] Ben Taha, Q. (2004) Soil Erosion in Jerash Area, Jordan. M.A. Thesis, University of Jordan, Amman. (In Arabic)

[21] Al-Shabatat, A. (2005) Environmental Deterioration and Land Management in the Petra-Showbak Area, Jordan. PhD Dissertation, University of Jordan, Amman. (In Arabic)

[22] Farhan, Y., Zreqat, D. and Farhan, I. (2013) Spatial Estimation of Soil Erosion Risk using RUSLE Approach, RS, and GIS Techniques: A Case Study of Kufranja Watershed, Northern Jordan. Journal of Water Resources and Protection, 5, 1247-1261. https://doi.org/10.4236/jwarp.2013.512134

[23] Farhan, Y. and Nawaiseh, S. (2015) Spatial Assessment of Soil Erosion Risk using RUSLE and GIS Techniques. Environmental Earth Sciences, 74, 4649-4669. https://doi.org/10.1007/s12665-015-4430-7

[24] Ijam, A. and Tarawneh, E. (2012) Assessing of Sediment Yield for Wala Dam Catchment Area in Jordan. European Water, 38, 43-58.

[25] Ijam, A. and Al-Mahamid, M. (2012) Predicting Sedimentation at Mujib Dam Reservoir in Jordan. Jordan Journal of Civil Engineering, 6, 448-463.

[26] Al-Sheriadeh, M.S. and Al-Hamdan, A.Z. (1999) Erosion Risk Assessment and Sediment Yield Production of King Talal Watershed, Jordan. Environmental Geology, 37, 234-242. https://doi.org/10.1007/s002540050381

[27] Al-Sherideh, M.S., Malkawi, A., Al-Hamdan, H. and Abdulrahman, N. (2000) Evaluating Sediment Yield at King Talal Reservoir from Landslides along Irbid-Amman Highway. Engineering Geology, 56, 361-342. https://doi.org/10.1016/S0013-7952(99)00119-2

[28] Al-Ansari, N. and Knutsson, S. (2010) Reduction of the Storage Capacity of Two Small Reservoirs in Jordan. Journal of Earth Science and Geotechnical Engineering, 2, 12-37.

[29] Farhan, Y. and Nawayse, S. (2018) Rainfall Erosivity in Jordan, in Review.

[30] Gupta, K., Deelstra, J. and Sharma, K. (1997) Estimation of Water Harvesting Potential for a Semiarid Area using GIs and Remote Sensing. IASH Publications Series of Proceedings and Report, International Association of Hydrological Sciences, No. 242, 53-62.

[31] Biswas, S., Sudhakar, S. and Desai, V.R. (1999) Prioritization of Sub-Watersheds Based on Morphometric Analysis of Drainage Basins: A Remote Sensing and GIS Approach. Journal of the Indian Society of Remote Sensing, 27, 155-166. 
https://doi.org/10.1007/BF02991569

[32] Kumar, M.G., Agarwal, A. and Bali, R. (2008) Delineation of Potential Sites for Water Harvesting Structures using Remote Sensing and GIS. Journal of the Indian Society of Remote Sensing, 36, 323-334. https://doi.org/10.1007/s12524-008-0033-z

[33] Chowdary, V., Ramakrishnan, D., Srivastava, Y., Chandran, V. and Jeyaram, A. (2009) Integrated Water Resources Development Plan for Sustainable Management of Mayurakshi Watershed, India using Remote Sensing and GIS. Water Resources Management, 23, 1581-1602. https://doi.org/10.1007/s11269-008-9342-9

[34] Javed, A., Khanday, M.A. and Rias, S. (2011) Watershed Prioritization using Morphometric and Land Use/Land Cover Parameters: A Remote Sensing and GIS Approach. Journal Geological Society of India, 79, 63-75.

https://doi.org/10.1007/s12594-011-0068-6

[35] Patel, D., Dholakia, M., Naresh, N. and Srivastava, P. (2012) Water Harvesting Structure Positioning by using Geo-Visualization Concept and Prioritization of Mini-Watersheds through Morphometric Analysis in the Lower Tapi Basin. Journal of the Indian Society of Remote Sensing, 40, 299-312.

https://doi.org/10.1007/s12524-011-0147-6

[36] Patel, D., Gajjar, C. and Srivastara, P. (2013) Prioritization of Malesari Mini-Watersheds through Morphometric Analysis: A Remote Sensing and GIS Perspective. Environmental Earth Sciences, 69, 2643-2656. https://doi.org/10.1007/s12665-012-2086-0

[37] Khanday, M.Y. and Javed, A. (2016) Prioritization of Sub-Watersheds for Conservation Measures in a Semi-Arid Watershed using Remote Sensing and GIS. Journal Geological Society of India, 88, 185-196. https://doi.org/10.1007/s12594-016-0477-7

[38] Makwana, J. and Tiwari, M. (2016) Prioritization of Agricultural Watersheds in Semi Arid Middle Region of Gujarat using Remote Sensing and GIS. Environmental Earth Sciences, 75, 137-159. https://doi.org/10.1007/s12665-015-4935-0

[39] Farhan, Y., Anbar, A., Al-Shaikh, N. and Mousa, R. (2017) Prioritization of Semi-Arid Agricultural Watershed using Morphometric and Principal Component Analysis, Remote Sensing, and GIS Techniques, the Zarqa River Watershed, Northern Jordan. Agricultural Sciences, 8, 113-148. https://doi.org/10.4236/as.2017.81009

[40] Suresh, M., Sudhakar, S., Tiwari, K.M. and Chowdary, V.M. (2004) Prioritization of Watersheds using Morphometric Parameters and Assessment of Surface Water Potential using Remote Sensing. Journal of the Indian Society of Remote Sensing, 32, 249-259. https://doi.org/10.1007/BF03030885

[41] NookaRatnam, K., Srivastava, U.K., Venkateshwara, Rao, V., Amminedu, E. and Murthy, K.S.R. (2005) Check Dam Positioning and Prioritization of $\mathrm{Mi}$ cro-Watersheds using SYI Model and Morphometric Analysis-Remote Sensing and GIS Perspective. Journal of the Indian Society of Remote Sensing, 33, 25-38. https://doi.org/10.1007/BF02989988

[42] Javed, A., Khanday, M.A. and Ahmad, R. (2009) Prioritization of Sub-Watersheds Based on Morphometric and Land Use Analysis in Guna District (M.P.); A Remote Sensing and GIS Approach. Journal of the Indian Society of Remote Sensing, 37, 261-274. https://doi.org/10.1007/s12524-009-0016-8

[43] Patel, D.P. and Dholakia, M. (2010) Feasible Structural and Non-Structural Measures to Minimize Effect of Flood in Lower Tapi Basin. International Journal WSEAS Transactions of Fluid Mechanics, 3, 104-121.

[44] Gajbhiye, S., Mishra, S.K. and Pandey, A. (2014) Prioritizing Erosion-Prone Area through Morphometric Analysis: An RS and GIS Perspective. Applied Water Science, 4, 51-61. https://doi.org/10.1007/s13201-013-0129-7 
[45] Gajbhiye, S.M. and Sharma, S.K. (2017) Prioritization of Watersheds through Morphometric Parameters: A PCA Approach. Applied Water Science, 7, 1505-1519. https://doi.org/10.1007/s13201-015-0332-9

[46] Chandniha, S.K. and Kansal, M.L. (2017) Prioritization of Sub-Watersheds Based on Morphometric Analysis using Geospatial Technique in PiperiyaWatershed, India. Applied Water Science, 7, 329-338. https://doi.org/10.1007/s13201-014-0248-9

[47] Chopra, R., Dhiman, R. and Sharma, P.K. (2005) Morphometric Analysis of Sub-Watersheds in Gurdaspur District, Punjab using Remote Sensing and GIS Techniques. Journal of the Indian Society of Remote Sensing, 33, 531-539. https://doi.org/10.1007/BF02990738

[48] Singh, N. and Singh, K.K. (2017) Geomorphological Analysis and Prioritization of Sub-Watersheds using Snyder's Unit Hydrograph Method. Applied Water Sciences, 7, 274-283. https://doi.org/10.1007/s13201-014-0243-1

[49] Hlaing, K., Haruyama, S. and Aye, M. (2008) Using GIS Based Distributed Soil Loss Modeling and Morphometric Analysis to Prioritize Watersheds for Soil Conservation in Bago River Basin of Lower Mynmar. Frontiers of Earth Science in China, 2, 465-478. https://doi.org/10.1007/s11707-008-0048-3

[50] Farhan, Y. and Anaba, O. (2016) Watershed Prioritization Based on Morphometric Analysis and Soil Loss Modeling in WadiKerak (Southern Jordan) using GIS Techniques. International Journal of Plant and Soil Science, 10, 1-18. https://doi.org/10.9734/IJPSS/2016/25321

[51] Farhan, Y. and Anaba, O. (2016) A Remote Sensing and GIS Approach for Prioritization of W. Shueib Min-Watersheds (Central Jordan) Based on Morphometric and Soil Erosion Susceptibility Analysis. Journal of Geographic Information System, 8, 1-19. https://doi.org/10.4236/jgis.2016.81001

[52] Jaiswal, R., Thomas, T., Galkate, R., Ghosh, N. and Singh, S. (2014) Watershed Prioritization using Saaty's AHP Based Decision Support for Soil Conservation Measures. Water Resources Management, 28, 475-494. https://doi.org/10.1007/s11269-013-0494-x

[53] Abdul Rahaman, S., Abdul Ajeez, S., Aruchamy, S. and Jegankuwar, R. (2015) Prioritization of Sub Watersheds Based on Morphometric Characteristics using Fuzzy Analytical Hierarchy Process and Geographical Information System-A Study of Kallar Watershed, Tamil Nadu. Aquatic Procedia, 4, 1322-1330. https://doi.org/10.1016/j.aqpro.2015.02.172

[54] Burdon, D. (1959) Handbook of the Geology of Jordan. Benham and Co., Colchester.

[55] Bender, F. (1975) Geology of the Arabian Peninsula: Jordan. United States Geological Survey Professional Paper 560, Washington DC.

[56] Al-Bakri, J. and Al-Jahmany, Y. (2013) Application of GIS and Remote Sensing to Groundwater Exploration in Al-Wala Basin in Jordan. Journal of Water Resources and Protection, 5, 962-971. https://doi.org/10.4236/jwarp.2013.510099

[57] Horton, R. (1945) Erosional Development of Streams and Their Drainage Basins: Hydrophysical Approach to Quantitative Morphology. Geological Society of America Bulletin, 56, 275-370. https://doi.org/10.1130/0016-7606(1945)56[275:EDOSAT]2.0.CO;2

[58] Strahler, A. (1957) Quantitative Analysis of Watershed Geomorphology. Transactions, American Geophysical Union, 38, 913-920. https://doi.org/10.1029/TR038i006p00913

[59] Strahler, A. (1964) Quantitative Geomorphology of Drainage Basins and Channel 
Networks. In: Chow, V., Ed., Handbook of Applied Hydrology, McGraw-Hill, New York, 439-476.

[60] Kanth, T. and Hassan, Z. (2012) Morphometric Analysis and Prioritization of Watersheds for Soil and Water Resources Management in Water Catchment using Geo Spatial Tools. International Journal of Geology, Earth and Environmental Sciences, 2, 30-41.

[61] Strahler, A. (1952) Dynamic Basis of Geomorphology. Geological Society of America Bulletin, 63, 923-938. https://doi.org/10.1130/0016-7606(1952)63[923:DBOG]2.0.CO;2

[62] Strahler, A. (1958) Dimensional Analysis Applied to Fluvially Eroded Landforms. Geological Society of America Bulletin, 69, 279-300. https://doi.org/10.1130/0016-7606(1958)69[279:DAATFE]2.0.CO;2

[63] Prasad, R.K., Mondal, N.C., Banerjee, P., Nandakumar, N.V. and Singh, V.S. (2008) Deciphering Potential Groundwater Zone in Hard Rock through the Application of GIS. Environmental Geology, 55, 467-475. https://doi.org/10.1007/s00254-007-0992-3

[64] Sreedevi, P., Sreekanth, P., Khan, H. and Ahmed, S. (2013) Drainage Morphometry and Its Influence on Hydrology in an Semi Arid Region: Using SRTM Data and GIS. Environmental Earth Sciences, 70, 839-848. https://doi.org/10.1007/s12665-012-2172-3

[65] Altat, F., Meraj, G. and Romshoo, S.A. (2013) Morphometric Analysis to Infer Hydrological Behavior of Lidder Watershed. Western Himalaya, India. Geography Journal, 13, 1-14.

[66] Tucker, G.E. and Bras, R.L. (1998) Hillslope Processes, Drainage Density, and Landscape Morphology. Water Resources Research, 34, 2751-2764. https://doi.org/10.1029/98WR01474

[67] Schumm, S. (1956) Evolution of Drainage Systems in Badlands of Perth Amboy, New Hersey. Geological Society of America Bulletin, 67, 464-597. https://doi.org/10.1130/0016-7606(1956)67[597:EODSAS]2.0.CO;2

[68] Gravelius, H. (1914) Grundriß der gesamtenGewässerkunde, Band 1: Flußkunde. Compendium of Hydrology, 1, 265-278.

[69] Zavoianu, I. (1985) Morphometry of Drainage Basins (Developments in Water Science). Elsevier, Amsterdam.

[70] Miller, V. (1953) A Quantitative Geomorphic Study of Drainage Basin Characteristics in the Clinch Mountain Area, Virginia and Tennessee. Project NR 389-402, Technical Report 3, Columbia University, Department of Geology, ONR, New York.

[71] Anderson, J. Hardy, E., Roach, H. and Witmer, R. (1976) A Land Use and Land Cover Classification System for Use with Remote Sensor Data. US Geological Survey Professional Paper 964, Washington DC.

[72] Ministry of Agriculture, Jordan (1995) The Soils of Jordan. Report of the National Soil Map and Land Use Project. Ministry of Agriculture, Hunting Technical Services LTD and European Commission, Amman.

[73] Al-Saady, Y., Al-Suhail, Q., Al-Tawash, B. and Othman, A. (2016) Drainage Network Extraction and Morphometric Analysis using Remote Sensing and GIS Mapping Techniques (Lesser Zab River Basin, Iraq and Iran). Environmental Earth Sciences, 75, 1243. https://doi.org/10.1007/s12665-016-6038-y

[74] Chorley, R., Donald, M. and Pogrzelski, H. (1957) A New Standard for Estimating 
Drainage Basin Shape. American Journal of Science, 255, 138-141.

https://doi.org/10.2475/ajs.255.2.138

[75] Farhan, Y. (2017) Morphometric Assessment of Wadi Wala Watershed, Southern Jordan using ASTER (DEM) and GIS. Journal of Geographic Information System, 9, 158-190. https://doi.org/10.4236/jgis.2017.92011

[76] Kaliraj, N., Chandrasekar, N. and Magesh, S. (2015) Morphometric Analysis of the River Thamirabarani Sub-Basin in KanyaKumari District, South West Coast of Tamil Naud, India. Using Remote Sensing and GIS Environmental Earth Sciences, 73, 7375-7401.

[77] Magesh, N.S., Chandrasekar, N. and Soundranagyagam, J.P. (2011) Morphometric Evaluation of Papanasam and Manimuthar Watersheds, Part of Western Ghats, Tirunelveli District, Tamil Nadu, India: A GIS Approach. Environmental Earth Sciences, 64, 373-381. https://doi.org/10.1007/s12665-010-0860-4

[78] Al-Alawi, M. and Abujamous, M. (2009) Estimation of Soil Erosion in Jordan by Using GIS. In: De Amicis, R., et al., Eds., Geospatial Visual Analytics, Geographical Information Processing and Visual Analytics for Environmental Security, Springer, Berlin, 439-450.

[79] Mhangara, P., Kakembo, V. and Lim, K.J. (2012) Soil Erosion Risk Assessment of the Keiskamma Catchment, South Africa using GIS and Remote Sensing. Environmental Earth Sciences, 65, 2087-2092. https://doi.org/10.1007/s12665-011-1190-x

[80] Abu-Zreig, M.M., Tamimi, A. and Alazba, A.A. (2011) Soil Erosion Control and Moisture Conservation in Arid Land with Stone Cover. Arid Land Research and Management, 25, 297-307. https://doi.org/10.1080/15324982.2011.565859

[81] Thakkar, A.K. and Dhiman, S.D. (2007) Morphometric Analysis and Prioritization of Mini Watersheds in Mohr Watershed, Gujarat, using Remote Sensing and GIS Techniques. Journal of the Indian Society of Remote Sensing, 37, 313-321. https://doi.org/10.1007/BF02990787 